\title{
Streptomyces deccanensis sp. nov., an alkaliphilic species isolated from soil
}

\author{
Syed G. Dastager, ${ }^{1}$ Chang-Jin Kim, ${ }^{1}$ Jae-Chan Lee, ${ }^{1}$ Dayanand Agasar, ${ }^{2}$ \\ Dong-Jin Park ${ }^{1}$ and Wen-Jun $\mathrm{Li}^{3}$
}

Correspondence
Dayanand Agasar
iamdaya62@rediffmail.com

\author{
${ }^{1}$ Korea Research Institute of Bioscience and Biotechnology, 52 Oeundong, Yusong, \\ Daejeon 305-333, Republic of Korea \\ ${ }^{2}$ Department of Studies \& Research in Microbiology, Gulbarga University, Gulbarga 585 106, \\ Karnataka, India \\ ${ }^{3}$ Yunnan Institute of Microbiology, Yunnan University, Kunming, Yunnan 650091, PR China
}

\begin{abstract}
A novel actinomycete strain, DAS $-139^{\top}$, was isolated from a soil sample collected from Gulbarga, Karnataka Province, India. The isolate was characterized by white to grey aerial mycelium. Long spore chains were found on the aerial mycelium and the aerial mycelium was composed of non-motile spores with hairy surfaces. The cell wall of strain DAS- $139^{\top}$ contained LL-diaminopimelic acid isomer as the diagnostic diaminoacid indicating that the cell wall was of chemotype-I. The predominant menaquinones were MK-9 $\left(\mathrm{H}_{6}\right)(76 \%), \mathrm{MK}-9\left(\mathrm{H}_{4}\right)(14 \%)$ and MK-9 $\left(\mathrm{H}_{8}\right)$ (10\%). Phosphatidylethanolamine was the diagnostic phospholipid. On the basis of 16S rRNA gene sequence, phenotypic and phylogenetic analyses, the novel strain was identified as a member of the genus Streptomyces. The novel strain grew optimally at $28{ }^{\circ} \mathrm{C}$ and $\mathrm{pH} 9.0$. The $\mathrm{G}+\mathrm{C}$ content of the genomic DNA was $71.8 \mathrm{~mol} \%$. 16S rRNA gene sequence analysis showed that the novel isolate had $99.4 \%$ sequence similarity with Streptomyces scabiei ATCC $49173^{\top}$ and $99.2 \%$ similarity with Streptomyces diastachromogenes ATCC $12309^{\top}$.

Furthermore, DNA-DNA hybridization with these two Streptomyces species showed 36.0 and $43.0 \%$ relatedness, respectively. Based on these observations, strain DAS $-139^{\top}$ is proposed to represent a novel species of the genus Streptomyces, for which the name Streptomyces deccanensis sp. nov. is proposed with the type strain DAS $-139^{\top}\left(=\mathrm{KCTC} 19241^{\top}=\mathrm{CCTCC}\right.$ AA $207004^{\top}$ ).
\end{abstract}

The genus Streptomyces represents a group of microorganisms that is widely distributed in nature. The genus Streptomyces remains a focus of systematic research, not only because members of this genus are still the most promising sources of commercially significant compounds, but also because current molecular biological methods are having an increasing impact on conventional Streptomyces systematics based on phenotypic characteristics (Williams et al., 1983). A polyphasic approach with a judicious combination of genotypic and phenotypic features can provide useful information for the classification of this complex group and for the recognition of novel species. Molecular systematic methods, notably 16S rRNA gene sequencing, and phylogenetic analysis are having an increasing impact on the systematics of the genus Streptomyces (Kim et al., 1998, 2000; Kim \& Goodfellow, 2002; Li et al., 2002). The application of chemical methods

Abbreviation: ISP, International Streptomyces Project.

The GenBank/EMBL/DDBJ accession number for the 16S rRNA gene sequence of strain DAS- $139^{\top}$ is EF219459. has influenced the development of actinomycete systematics at the genus level and even at higher taxonomic levels (Goodfellow \& Cross, 1984; Kroppenstedt, 1985; Minnikin et al., 1980; Stackebrandt, 1986). With more than 500 recognized species and subspecies, the taxon currently harbours the largest number of species with validly published names in the domain Bacteria (Hain et al., 1997). The present study describes a distinct alkaliphilic actinomycetes strain, strain DAS- $139^{\mathrm{T}}$, as a novel species of the genus Streptomyces based on a polyphasic approach.

Strain DAS-139 ${ }^{\mathrm{T}}$ was isolated from a soil sample taken from the Gulbarga region, Karnataka Province, Deccan Trap, India, after 2 weeks incubation at $28{ }^{\circ} \mathrm{C}$ on glycerolasparagine agar [ISP medium 5 (Shirling \& Gottlieb, 1966)]. Morphological, physiological and biochemical characterization of strain DAS $-139^{\mathrm{T}}$ was carried out by following the standard protocol of the International Streptomyces Project (Shirling \& Gottlieb, 1966, 1968a, b). For colour determination, samples were compared with colour chips from ISCC-NBS Color Charts standard sample no. 2106 (Kelly, 1964). Microscopic observation 
of spores and mycelia of strain DAS- $139^{\mathrm{T}}$ grown on ISP 2 for 21 days were made by light microscopy (BH-2; Olympus) and scanning electron microscopy (JSM5600LV; JEOL). The novel strain was examined for a range of phenotypic properties using standard procedures (Shirling \& Gottlieb, 1966; Williams et al., 1983), except that $\mathrm{pH}$ was regulated by using autoclaved $\mathrm{Na}_{2} \mathrm{CO}_{3}$. The following buffers were used to control the $\mathrm{pH}$ range; $\mathrm{pH}$ 6.0, 7.0 and 8.0, 0.1 $\mathrm{M} \mathrm{KH}_{2} \mathrm{PO}_{4} / 0.1 \mathrm{M} \mathrm{NaOH}$; $\mathrm{pH} 9.0$ and 10.0, 0.1 $\mathrm{M} \mathrm{NaHCO}_{3} / 0.1 \mathrm{M} \mathrm{Na}_{2} \mathrm{CO}_{3} ; \mathrm{pH} 11.0,0.05 \mathrm{M}$ $\mathrm{Na}_{2} \mathrm{HPO}_{4} / 0.1 \mathrm{M} \mathrm{NaOH}$ and $\mathrm{pH} 12.0,0.2 \mathrm{M} \mathrm{KCl} / 0.2 \mathrm{M}$ $\mathrm{NaOH}$. Strain DAS- $139^{\mathrm{T}}$ was incubated in liquid ISP 2 medium for 2-3 weeks, $\mathrm{pH}$ was regulated after sterilization of the media to $\mathrm{pH} 6.0,7.0,8.0,9.0,10.0,11.0$ and 12.0 using autoclaved $\mathrm{KOH}, \mathrm{K}_{2} \mathrm{CO}_{3}, \mathrm{NaOH}$ or $\mathrm{Na}_{2} \mathrm{CO}_{3}$. Tolerance to temperature and $\mathrm{NaCl}$ was determined on modified ISP 2 medium followed by incubation at $28{ }^{\circ} \mathrm{C}$ for 3-4 weeks.

Cell-wall amino acid was purified and analysed by the methods of Jiang et al. (2001). The procedure of Lechevalier \& Lechevalier (1980) was used for analysis of whole-cell sugars. Menaquinones and phospholipids were extracted from freeze-dried biomass and purified according to Collins (1985) and Minnikin et al. (1984) and finally analysed by HPLC. Fatty acid composition was determined by following the procedures of Komagata \& Suzuki (1987) and Takeuchi \& Hatano (1998).

Genomic DNA was extracted and the 16S rRNA gene was amplified as described by Cui et al. (2001). The DNA G + C content of strain DAS- $139^{\mathrm{T}}$ was determined using the thermal denaturation method (Marmur \& Doty, 1962). Reference strains were chosen from BLAST (Altschul et al., 1997) search results. Phylogenetic analysis was performed using the software package MEGA version 2.1 (Kumar et al., 2001) after multiple alignment of data by CLUSTAL_X (Thompson et al., 1997). A phylogenetic tree was reconstructed using the neighbour-joining method of Saitou \& Nei (1987) from $K_{\text {nuc }}$ values (Kimura, 1980). The topology of the phylogenetic tree was evaluated by using the bootstrap resampling method of Felsenstein (1985) with 1000 replicates.

Morphological observation of a 21 day culture of strain DAS- $139^{\mathrm{T}}$ grown on yeast extract/malt extract agar (ISP 2 medium) revealed that strain DAS- $139^{\mathrm{T}}$ had the typical characteristics of the genus Streptomyces. Aerial mycelium and substrate mycelium were well-developed without fragmentation. Long chains of spores were straight, hairy and non-motile (Fig. 1). Strain DAS $-139^{\mathrm{T}}$ could grow well at between $\mathrm{pH} 7.0$ and 12.0, with an optimum $\mathrm{pH}$ value of 9.0-10.0. The optimum growth temperature was $28{ }^{\circ} \mathrm{C}$. Strain DAS $-139^{\mathrm{T}}$ grew in presence of $0-5 \% \mathrm{NaCl}(\mathrm{w} / \mathrm{v})$. Mycelium of strain DAS- $139^{\mathrm{T}}$ was well developed on most media tested including yeast extract/malt extract agar (ISP 2), oatmeal agar (ISP 3), glycerol-asparagine agar (ISP 5), tyrosine agar (ISP 7) and Czapek's agar. The novel strain showed poor growth on inorganic salt-starch agar (ISP 4)
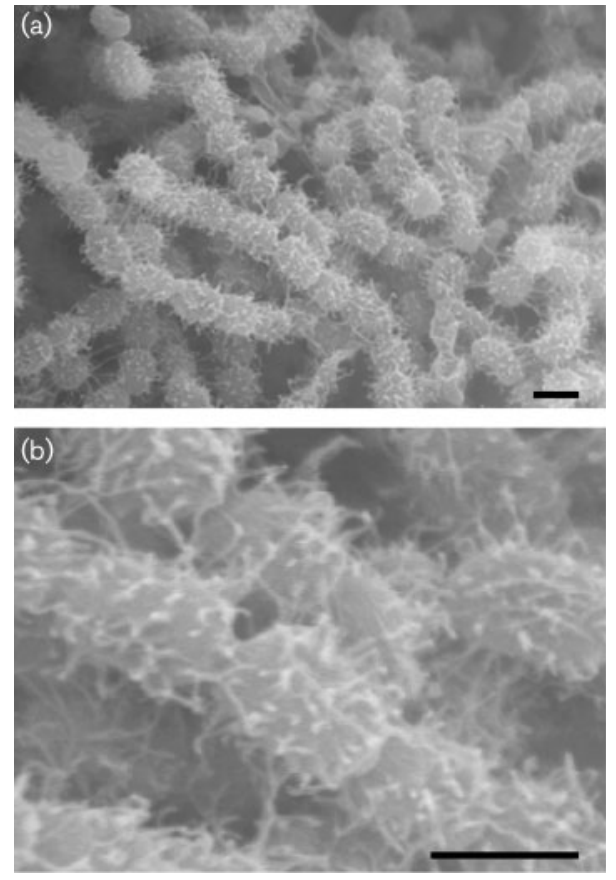

Fig. 1. Scanning electron micrographs indicating the spore chain morphology of strain DAS-139 $13{ }^{\top}$. (a) Spores in straight chains; (b) hairy appearance of spores. Bars, $1 \mu \mathrm{m}$.

and nutrient agar (Table 1). Diffusible pigments were observed in test media and melanin was produced on peptone-yeast extract-iron agar.

The cell wall of strain DAS- $139^{\mathrm{T}}$ contained LL-diaminopimelic acid and glycine as the diagnostic diamino acids, which indicated that it has a cell-wall of chemotype I (Lechevalier \& Lechevalier, 1970a, b). No diagnostic sugars were detected in whole-cell hydrolysates. Phosphatidylethanolamine is a diagnostic phospholipid detected (phospholipid type II sensu Lechevalier et al., 1977). The predominant menaquinones were MK- $9\left(\mathrm{H}_{6}\right)(76 \%)$, MK$9\left(\mathrm{H}_{4}\right)(14 \%)$ and MK-9 $\left(\mathrm{H}_{8}\right)(10 \%)$. The major fatty acids found were iso- $\mathrm{C}_{16: 0}(30 \%)$, anteiso- $\mathrm{C}_{15: 0}(16 \%)$, iso$\mathrm{C}_{15: 0}(12 \%)$, anteiso- $\mathrm{C}_{17: 0}(9 \%)$, iso- $\mathrm{C}_{16: 1}(7 \%)$ and iso$\mathrm{C}_{14: 0}(6 \%)$. Thus, chemotaxonomic and phenotypic data showed that strain DAS- $139^{\mathrm{T}}$ should be assigned to the genus Streptomyces.

The almost-complete 16S rRNA gene sequence (1524 nt) of strain DAS- $139^{\mathrm{T}}$ was aligned manually with the corresponding partial 16S rRNA sequences of the type strains of representative members of the genus Streptomyces retrieved from the GenBank, EMBL and DDBJ databases by using BLAST (Altschul et al., 1997). Phylogenetic analyses based on 16S rRNA gene sequences showed that the novel isolate falls into one distinct subclade with Streptomyces scabiei ATCC $49173^{\mathrm{T}}$ (GenBank accession no. D63862) and Streptomyces diastatochromogenes ATCC $12309^{\mathrm{T}}$ (D63867) with which it shared 16S rRNA gene sequence similarity of 
Table 1. Culture characteristics of strain DAS $-139^{\top}$ on various ISP media

Colours were taken from ISCC-NBS Color Chart standard sample no. 2106 (Kelly, 1964). Plates were incubated for 3-4 weeks at $28{ }^{\circ} \mathrm{C}$.

\begin{tabular}{|llcccc|}
\hline Medium & Growth & Sporulation & Diffusible pigment & & \multicolumn{2}{c|}{ Colony colour } \\
\cline { 3 - 6 } & & & & Aerial mycelium & Substrate mycelium \\
\hline Yeast extract agar (ISP 2) & Good & Good & Yellow & Yellow-brown & Grey-yellow \\
Oatmeal agar (ISP 3) & Good & Good & Brown & White & Reddish brown \\
Inorganic salts-starch agar (ISP 4) & Poor & Poor & Absent & White & Light yellow \\
Glycerol-asparagine agar (ISP 5) & Good & Good & Reddish brown & Light pink & Reddish brown \\
Tyrosine agar (ISP 7) & Good & Good & Black & Dark pink & Dark brown \\
Czapek's agar & Good & Moderate & Pale yellow & Pink & Dark reddish \\
Nutrient agar & Good & Moderate & Absent & Light brown & Grey-reddish \\
& & & & &
\end{tabular}

$>99.0 \%$ (11 and 17 nucleotide differences out of 1524 , respectively). The phylogenetic tree based on the $16 \mathrm{~S}$ rRNA gene sequence of strain DAS $-139^{\mathrm{T}}$ and most closely related type strains of species of the genus Streptomyces is shown in Fig. 2. DNA-DNA relatedness tests were performed between strain DAS-139 ${ }^{\mathrm{T}}$, S. scabiei ATCC $49173^{\mathrm{T}}$ and S. diastatochromogenes ATCC $12309^{\mathrm{T}}$ using the optical renaturation method (De Ley et al., 1970; Huß et al., 1983; Jahnke, 1992). The DNA-DNA relatedness values of strain DAS- $139^{\mathrm{T}}$ with S. scabiei ATCC $49173^{\mathrm{T}}$ and S. diastatochromogenes ATCC $12309^{\mathrm{T}}$ were $36 \%(36 \pm 0.3)$ and $43.0 \%$, respectively, and both values were significantly lower than $70 \%$, the level considered to be the threshold value for the delineation of genomic species (Wayne et al., 1987). Phenotypic comparisons were made between strain DAS- $39^{\mathrm{T}}$ and closely related species of the genus Streptomyces in order to differentiate strain DAS $139^{\mathrm{T}}$ (Table 2). The G $+\mathrm{C}$ content of the DNA of strain DAS- $139^{\mathrm{T}}$ was $71.8 \mathrm{~mol} \%$. On the basis of morphological, chemotaxonomic and phylogenetic evidence and physiological and biochemical distinctiveness, it is suggested that strain DAS $-139^{\mathrm{T}}$ is a new member of the genus Streptomyces, for which the name Streptomyces deccanensis sp. nov. is proposed.

\section{Description of Streptomyces deccanensis sp. nov.}

Streptomyces deccanensis [dec.can.en'sis. N.L. masc. adj. deccanensis pertaining to Deccan Trap, India, the geographical region (Gulbarga) from where the type strain was isolated].

Gram-positive, aerobic, non-motile, alkalitolerant and thermotolerant with good growth of hyphae without fragmentation. Long, hairy, oval-shaped spores are arranged in straight chains. Grows well on almost all media tested (mentioned in Table 1). Colonies are whitish to pink, smooth, powdery and $0.5-1.0 \mathrm{~mm}$ in diameter. Casein and cellulose are degraded. Positive in tests for nitrate reduction and gelatin liquefaction. Soluble pigments are observed in all test media and melanin is observed in peptone-yeast extractiron agar. The temperature range for growth is $28-45^{\circ} \mathrm{C}$, with an optimum at $40{ }^{\circ} \mathrm{C}$. Grows at $\mathrm{pH} 7-12$ and in the presence of $7 \% \mathrm{NaCl}$. Good growth is found on almost all carbon sources tested, more detailed phenotypic properties are mentioned in Table 2. Cell wall contains LL-diaminopimelic acid and glycine. Whole-cell hydrolysates mainly contain galactose and glucose and no diagnostic sugars. Predominant menaquinones are $\mathrm{MK}-9\left(\mathrm{H}_{6}\right)$ (76\%),

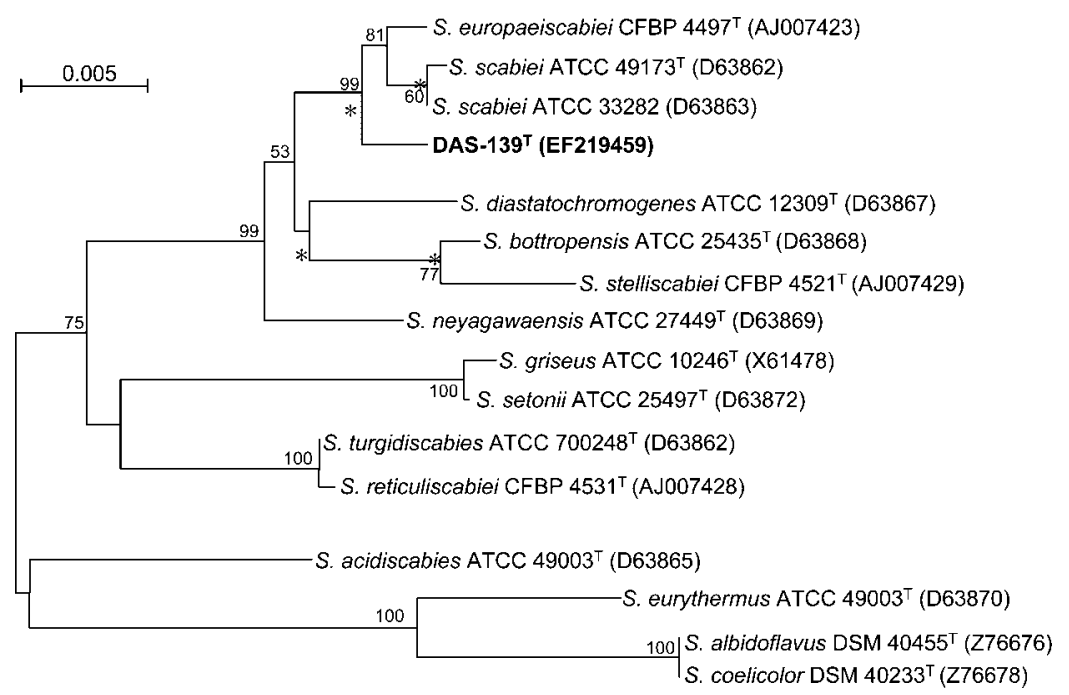

Fig. 2. Phylogenetic dendrogram obtained by distance matrix analysis of $16 \mathrm{~S}$ rRNA gene sequences, showing the position of strain DAS- $139^{\top}$ among its phylogenetic neighbours. Asterisks indicate branches that were recovered using least-squares (Fitch \& Margoliash, 1967), maximum-likelihood (Felsenstein, 1981) and maximum-parsimony (Kluge \& Farris, 1969) algorithms. Numbers at the branch nodes are bootstrap values, expressed as a percentage of 1000 replicates (only values above $50 \%$ are shown). Bar, 0.005 substitutions per nucleotide position. 
Table 2. Morphological and phenotypic characteristics that differentiate strain DAS $-139^{\top}$ from closely related species of the genus Streptomyces

Taxa: 1, strain DAS- $139^{\mathrm{T}} ; 2, \quad$ S. scabies ATCC $49173^{\mathrm{T}} ; 3, S$. diastatochromogenes ATCC $12309^{\mathrm{T}}$. + , Positive; -, negative; ND, not determined; R, red; OB, olive brown; GY, greyish yellow; SC, straight chains; RF, rectiflexibiles. Data for reference strains were taken from Shirling \& Gottlieb (1968a, b; 1969), Williams et al. (1983). All taxa were able to use the following as a carbon source: D-glucose, Larabinose, sucrose, D-xylose, D-mannitol and D-fructose. All taxa were capable of degrading casein.

\begin{tabular}{|lccc|}
\hline Characteristic & $\mathbf{1}$ & $\mathbf{2}$ & $\mathbf{3}$ \\
\hline Colony morphology & White & Grey & Grey \\
Reverse side colour & $\mathrm{R}$ & OB & GY \\
Spore shape & Hairy & Smooth & Smooth \\
Spore chain & SC & RF & SC \\
Melanin & + & - & + \\
Soluble pigments & + & + & - \\
Degradation of: & & & \\
Cellulose & + & - & + \\
Pectin & - & - & ND \\
Starch & + & - & + \\
Growth at/with: & & & \\
NaCl $\%$, w/v) & 5.0 & $<4.0$ & $<7.0$ \\
$45{ }^{\circ}$ C & + & - & + \\
pH & $7-12$ & $7-8$ & 7.5 \\
Carbon utilization: & & & \\
myo-Inositol & + & - & + \\
Raffinose & + & - & + \\
L-Rhamnose & + & - & + \\
\hline
\end{tabular}

MK-9 $\left(\mathrm{H}_{4}\right)(14 \%)$ and MK-9 $\left(\mathrm{H}_{8}\right)(10 \%)$. The diagnostic phospholipid is phosphatidylethanolamine. Major fatty acid components are $\mathrm{C}_{16: 0}(29.78 \%)$, anteiso- $\mathrm{C}_{15: 0}(15.87 \%)$, iso- $\mathrm{C}_{15: 0} \quad(11.97 \%)$, anteiso- $\mathrm{C}_{17: 0}(9.23 \%)$, iso- $\mathrm{C}_{16: 1}$ $(7.24 \%)$ and iso- $\mathrm{C}_{14: 0}(5.88 \%)$, iso- $\mathrm{C}_{17: 1}(3.98), \mathrm{C}_{16: 0}$ (3.72) and iso- $\mathrm{C}_{17: 0}$ (3.66). Grows optimally at $28{ }^{\circ} \mathrm{C}$ and $\mathrm{pH}$ 9.0-10.0. The DNA G $+\mathrm{C}$ content is $71.8 \mathrm{~mol} \%$.

The type strain, DAS- $139^{\mathrm{T}}\left(=\right.$ KCTC $19241^{\mathrm{T}}=$ CCTCC AA $207004^{\mathrm{T}}$ ), was isolated from a soil sample collected from Gulbarga, Karnataka Province, Deccan Trap, India.

\section{Acknowledgements}

This work was supported by the 21C Frontier Microbial Genomics and Application Centre program Korean Ministry of Science \& Technology (MOST) and Korea Foundation for International Cooperation of Science \& Technology (KICOS) through a grant provided by MOST in Global Partnership Program (No. M60602000001-06E0200-00100), Republic of Korea. W.-J. L. was also supported by the Program for New Century Excellent Talent in University (NCET).

\section{References}

Altschul, S. F., Madden, T. L., Schaffer, A. A., Zhang, J., Zhang, Z., Miller, W. \& Lipman, D. J. (1997). Gapped BLAST and PSI_BLAST: a new generation of protein database search programs. Nucleic Acids Res 25, 3389-3402.

Collins, M. D. (1985). Isoprenoid quinone analysis in classification and identification. In Chemical Methods in Bacterial Systematics, pp. 267-287. Edited by M. Goodfellow \& D. E. Minnikin. London: Academic Press.

Cui, X. L., Mao, P. H., Tseng, M., Li, W. J., Zhang, L. P., Xu, L. H. \& Jiang, C. L. (2001). Streptomonospora gen. nov., a new member of the family Nocardiopsaceae. Int J Syst Evol Microbiol 51, 357-363.

De Ley, J., Cattoir, H. \& Reynaerts, A. (1970). The quantitative measurement of DNA hybridization from renaturation rates. Eur $J$ Biochem 12, 133-142.

Felsenstein, J. (1981). Evolutionary tree from DNA sequences: a maximum likelihood approach. J Mol Evol 17, 368-376.

Felsenstein, J. (1985). Confidence limits on phylogenies: an approach using the bootstrap. Evolution 39, 783-791.

Fitch, W. M. \& Margoliash, E. (1967). Construction of phylogenetic trees: a method based on mutation distances as estimated from cytochrome $c$ sequences is of general applicability. Science 155, 279-284.

Goodfellow, M. \& Cross, T. (1984). In Biology of the Actinomycetes, pp. 7-164. Edited by M. Goodfellow, M. Mordarski \& S. T. Williams. London: Academic Press.

Hain, T., Ward-Rainey, N., Kroppenstedt, R. M., Stackebrandt, E. \& Rainey, F. A. (1997). Discrimination of Streptomyces albidoflavus strains based on the size and number of 16S-23S ribosomal DNA intergenic spacers. Int J Syst Bacteriol 47, 202-206.

Huß, V. A. R., Festl, H. \& Schleifer, K. H. (1983). Studies on the spectrophotometric determination of DNA hybridization from renaturation rates. Syst Appl Microbiol 4, 184-192.

Jahnke, K. D. (1992). BASIC computer program for evaluation of spectroscopic DNA renaturation data from GILFORD SYSTEM 2600 spectrophotometer on a PC/XT/AT type personal computer. J Microbiol Methods 15, 61-73.

Jiang, L.-Y., Li, M.-G., Li, W.-J., Cui, X.-L., Xu, L.-H. \& Jiang, C.-L. (2001). Study on the application of quantitative analysis of cell-wall amino acids in actinomycetes classification. Wei Sheng Wu Xue Bao 41, 270-277 (in Chinese).

Kelly, K. L. (1964). Inter-Society Color Council-National Bureau of Standard Color-name charts illustrated with centroid colors. US Government Printing Office, Washington.

Kim, S. B. \& Goodfellow, M. (2002). Streptomyces avermitilis sp. nov., nom. rev., a taxonomic home for the avermectin-producing streptomycetes. Int J Syst Evol Microbiol 52, 2011-2014.

Kim, S. B., Falconer, C., Williams, E. \& Goodfellow, M. (1998). Streptomyces thermocarboxydovorans sp. nov. and Streptomyces thermocarboxydus sp. nov., two moderately thermophilic carboxydotrophic species from soil. Int J Syst Bacteriol 48, 59-68.

Kim, S. B., Al-Tai, A. M., Kim, S. B., Somasundaram, P. \& Goodfellow, M. (2000). Streptomyces thermocoprophilus sp. nov., a cellulose-free endo-xylanase-producing streptomycete. Int J Syst Evol Microbiol 50, 505-509.

Kimura, M. (1980). A simple method for estimating evolutionary rates of base substitutions through comparative studies of nucleotide sequence. J Mol Evol 16, 111-120.

Kluge, A. G. \& Farris, F. S. (1969). Quantitative phyletics and the evolution of anurans. Syst Zool 18, 1-32.

Komagata, K. \& Suzuki, K.-I. (1987). Lipid and cell wall analysis in bacterial systematics. In Methods in Microbiology, vol. 19, pp. 161207. London: Academic Press. 
Kroppenstedt, R. M. (1985). Fatty acid and menaquinones analysis of actinomycetes and related organisms. In Chemical Methods in Bacterial Systematics, pp. 173-199. Edited by M. Goodfellow \& D. E. Minnikin. London: Academic Press.

Kumar, S., Tamura, K., Jakobsen, I. B. \& Nei, M. (2001). MEGA2: molecular evolutionary genetics analysis software. Bioinformatics 17, 1244-1245.

Lechevalier, H. A. \& Lechevalier, M. P. (1970a). A critical evaluation of the genera of aerobic actinomycetes. In The Actinomycetales, pp. 393-405. Edited by H. Prauser. Jena: VEB Gustav Fischer.

Lechevalier, M. P. \& Lechevalier, H. A. (1970b). Chemical composition as a criterion in the classification of aerobic actinomycetes. Int J Syst Bacteriol 20, 435-443.

Lechevalier, M. P. \& Lechevalier, H. A. (1980). The chemotaxonomy of actinomycetes. In Actinomycete Taxonomy, pp. 22. Edited by Dietz, Thayer. Arlington, VA: Society for Industrial Microbiology.

Lechevalier, M. P., De Bièvre, C. \& Lechevalier, H. A. (1977). Chemotaxonomy of aerobic actinomycetes: phospholipid composition. Biochem Syst Ecol 5, 249-260.

Li, W., Lanoot, B., Zhang, Y., Vancanneyt, M., Swings, J. \& Liu, Z. (2002). Streptomyces scopiformis sp. nov., a novel streptomycete with fastigiate spore chains. Int J Syst Evol Microbiol 52, 1629-1633.

Marmur, J. \& Doty, P. (1962). Determination of the base composition of deoxyribonucleic acid from its thermal denaturation temperature. J Mol Biol 5, 109-118.

Minnikin, D. E., Hutchinson, I. G., Caldicott, A. B. \& Goodfellow, M. (1980). Thin-layer chromatography of methanolysates of mycolic acid-containing bacteria. J Chromatogr 188, 221-223.

Minnikin, D. E., O'Donnell, A. G., Goodfellow, M., Alderson, G., Athalye, M., Schaal, A. \& Parlett, J. H. (1984). An integrated procedure for the extraction of bacterial isoprenoid quinones and polar lipids. J Microbiol Methods 2, 233-241.
Saitou, N. \& Nei, M. (1987). The neighbor-joining method: a new method for reconstructing phylogenetic trees. Mol Biol Evol 4, 406-425.

Shirling, E. B. \& Gottlieb, D. (1966). Methods for characterization of Streptomyces species. Int J Syst Bacteriol 16, 313-340.

Shirling, E. B. \& Gottlieb, D. (1968a). Cooperative description of type cultures of Streptomyces. II. Species descriptions from first study. Int $J$ Syst Bacteriol 18, 69-189.

Shirling, E. B. \& Gottlieb, D. (1968b). Cooperative description of type cultures of Streptomyces. III. Additional species descriptions from first and second studies. Int J Syst Bacteriol 18, 279-392.

Shirling, E. B. \& Gottlieb, D. (1969). Cooperative description of type cultures of Streptomyces. IV. Species descriptions from the second, third and fourth studies. Int J Syst Bacteriol 19, 391-512.

Stackebrandt, E. (1986). The significance of wall type in phylogenetically based taxonomic studies on actinomyctes. In Biological, Biochemical and Biomedical Aspects of Actinomycetes, Part B, pp. 497-506. Edited by G. Szabo, S. Biro \& M. Goodfellow. Budapest: Academia Kiado.

Takeuchi, M. \& Hatano, K. (1998). Union of the genera Microbacterium Orla-Jensen and Aureobacterium Collins et al. in a redefined genus Microbacterium. Int J Syst Bacteriol 48, 739-749.

Thompson, J. D., Gibson, T. J., Plewniak, F., Jeanmougin, F. \& Higgins, D. G. (1997). The CLUSTAL_X windows interface: flexible strategies for multiple sequence alignment aided by quality analysis tools. Nucleic Acids Res 25, 4876-4888.

Wayne, L. G., Brenner, D. J., Colwell, R. R., Grimont, P. A. D., Kandler, O., Krichevsky, M. I., Moore, L. H., Moore, W. E. C., Murry, R. G. E. \& other authors (1987). International Committee on Systematic Bacteriology. Report of the ad hoc committee on reconciliation of approaches to bacterial systematics. Int J Syst Bacteriol 37, 463-464.

Williams, S. T., Goodfellow, M., Alderson, G., Wellington, E. M. H., Sneath, P. H. A. \& Sackin, M. J. (1983). Numerical classification of Streptomyces and related genera. J Gen Microbiol 129, 1743-1813. 